\title{
ETNOGRAFIA VISUAL E NARRATIVA ORAL: DA FABRICAÇÃO À DESCOBERTA DA IMAGEM
}

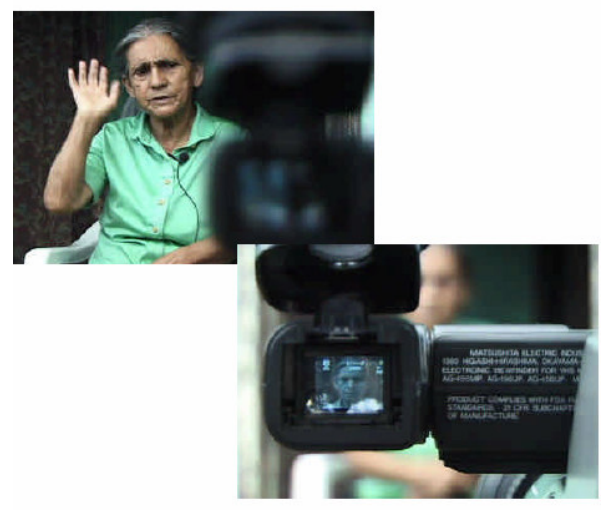

Rafael Victorino Devos

A Cidade vista das ilhas - do exotismo à necessidade do ponto de vista etnográfico

Ainda como iniciante na pesquisa etnográfica, tomei conhecimento da memória oral que se relaciona às ilhas de Porto Alegre, através de pesquisa exploratória que seguia a metodologia utilizada pela equipe do BIEV: escolhíamos espaços públicos significativos para o cotidiano da cidade (nesse caso, as ruas à beira do Lago Guaíba nas ilhas), para a realização de gravações em vídeo. Enquanto contemplávamos paisagens da cidade tantas vezes representadas por fotógrafos, pintores, cronistas, novas representações surgiam sobre elas: a voz de moradores, freqüentadores, admiradores de ruas, prédios, beiras de rio e outros tantos lugares da cidade. Tinha início a descoberta de narradores de itinerários de grupos urbanos, dos muitos "começos" das atuais formas da paisagem da cidade.

Foi em meio a esse trabalho que nos deparamos com uma memória da cidade de Porto Alegre muito diferente, relacionada às ilhas e águas do Bairro Arquipélago. O Arquipélago é formado por 16 ilhas, circundadas pelas águas dos rios Jacuí, Gravataí, Sinos, Caí e pelo Lago Guaíba. Elas encontram-se à entrada da cidade, à noroeste do centro da capital. No atual contexto urbano-industrial da cidade, as pequenas propriedades rurais na margem das ilhas passaram a dar lugar a grandes residências e clubes náuticos destinados ao lazer de classes economicamente privilegiadas (as chamadas "mansões" das ilhas), enquanto que sua parte mais próxima das pontes e estradas de acesso transformou-se em periferia, vila de classes populares de baixíssima renda.

Esse processo de transformação da paisagem do Arquipélago, em meio ao desenvolvimento da Região Metropolitana de Porto Alegre, é narrado de forma muito particular pelos chamados moradores "antigos" das ilhas, que nos contaram suas 
trajetórias pessoais em meio a um repertório de estórias em que figuras míticas e lendárias eram recorrentes, reconfigurando essa paisagem das ilhas. Colocava-se o desafio de representar no vídeo essa paisagem da cidade, vista das ilhas, a partir das imagens que essas narrativas iam nos revelando.

Trabalhando em equipe, sob a direção das antropólogas Ana Luiza Carvalho da Rocha e Cornelia Eckert, iniciei a pesquisa sobre esse tema, junto a esse grupo, e acabei desenvolvendo minha dissertação de mestrado e a minha formação como antropólogo, a partir do duplo lugar de pesquisador e documentarista (gravando e editando em vídeo imagens da pesquisa) que se constituiu sobretudo em ouvinte/narrador das estórias descobertas no trabalho de campo. Nesse artigo, pretendo discutir como questões próprias da produção de um documentário sobre o tema da narrativa oral e da representação da paisagem em vídeo ${ }^{1}$ puderam ser recolocadas como um problema de pesquisa e representação da alteridade, como uma etnografia, cujo problema de interpretação é realizado a partir da imagem, e pela imagem.

Ao falarem sobre a paisagem do Arquipélago, sobre as ilhas, banhados e canais de navegação, a memória dos narradores trazia outras imagens que transformavam a representação dessa paisagem. Ao invés de tentar inserir os relatos dessas pessoas em um roteiro pré-dado, era preciso mergulhar nessas estórias, ouvi-las muitas vezes, para descobrir uma estrutura e um sentido que não estava oculto, mas expresso na fala dessas pessoas, e que traziam ao seu ouvinte uma outra imagem desse espaço, atravessada pelos muitos tempos que a narrativa revela.

Realizar um documentário etnográfico e uma dissertação escrita sobre esse "trabalho da memória"2 de estetizar o tempo na narrativa oral, compunha portanto o desafio da composição da narrativa etnográfica, não apenas em vídeo, mas também na escrita, buscando a convergência dessas imagens que os narradores cadenciavam nos seus relatos, de forma a descobrir a paisagem do Arquipélago vista a partir dos relatos e gestos desses narradores. É por isso que apresento nesse artigo algumas páginas inteiras da dissertação, e alguns quadros congelados do documentário "A Morada das Águas" para discutir como essa relação narrativa/paisagem foi evocada nos dois suportes, em termos de representação da relação espaço/tempo/ação tanto na página escrita, tomada enquanto imagem a ser interpretada, quanto nas seqüências de áudio e vídeo.

\footnotetext{
${ }^{1}$ Por exemplo: O que perguntar e o que fazer na entrevista? Como "fazer as pessoas falarem"? Como deixá-las à vontade? Como conduzir a entrevista? Como enquadrar os narradores? Como selecionar e editar os relatos? Como representar em imagens suas narrativas?

${ }^{2}$ Cf. Bosi, 1987.
} 


\section{Memória e Inteligência Narrativa}

Muitas das pessoas mais velhas que viveram a infância em Porto Alegre, lembram da famosa enchente de 1941 que deixou as ilhas completamente submersas e o centro da cidade alagado por quase um mês. Nas ilhas, essa lembrança tem a força de um "começo" na história pessoal de muitos velhos moradores. Quando contei a Seu Adão sobre essa terrível enchente, narrando-lhe o que eu já ouvira e vira em fotografias, ele me surpreendeu ao contar as mais densas imagens de sua infância, tendo saudades de quando a família ficou "flagelada" em uma área mais elevada da região. Ao lhe perguntar sobre a descida das águas e a decisão da volta ao chão familiar, não era a casa levada pelas águas a imagem que o detinha no relato, mas o "bicho preto" que aparecia no terreno familiar:

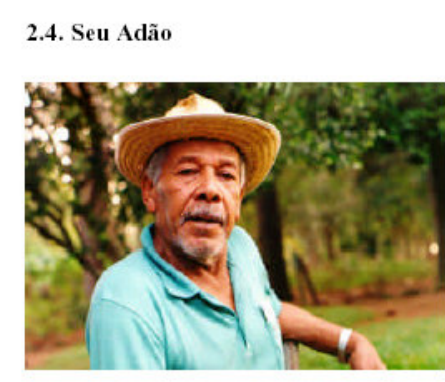

Isso ai foi na baixa de 40 , na baixa da enchente, (..) Eu não me lembro, mas, demorou um pouco.

Acho que levou, quase un mês, eu acho, pra baixar.

E quase um més, por aí, né? E depois quando baixou.

pra beira do rio, né? Com a mochila atrás, tudo.

Entâo não tinha casa, não tinha nada. Que que ia fazê, né?

Só a roupa de cama, e as panela.

Ai fomo parar num galpáo, ali em cima.

Paremo naquele galpão.

Paremo naquele galpão.
Tudo bem. Agora vô contar a estória.

Tudo bem. Agora vô contar a estória.
Tudo bem, paremo ali. Nós, os véio parava pra lá, assim, no galpào, e nós dormala no chiquero, chiquero era o celero.

Mas o chiquero era aberto assim, que nem isso aqui assim, ó.

Por baixo era aberto assim, né?

Tudo bem.

Rapaz! A cachorrada

Era noite e dia, rapaz, aqueles cachorro.

Aqueles cachorro desconfiavam das coisas.

Corriam que chegavam a chorar em roda da gente, que a gente dormia e aqueles cachorro.

Tá, tudo bem.

Agora vou contar. Isso, não... Eu vi, né? Eu vi.

Então a mãe falava assim, no tal de bicho preto, é, porque o bicho preto, passa aqui, onde ele passa ele arranha o chão, né, tudo.

Nós ficava: - Será que a mãe nâo tá mentindo?

Nós uns pros otro, né? Deus u livre duvidar da véia.

Aí ún dia de manhã, né, a cachorrada tava doida.

Doida, mas eles se enfiavam, enfiavam galpão a dentro os

cachorro.

Casa não tinha, né? Era o galpâo, só.

Olha, rapaz!

Eu vi um cachorro preto, desse tamanho!
Mas um baita dum cachorro, comprido assim, sabe?

Comprido assim, e dessa altura assim.

Era um cavalinho. Era um cavalinho.

E eu olhando bem e o cachorro passou correndo pela bèra da

estrada e eu chamei

- Ô Jorge, ô Reco, ô Tereza!

Chamei a minha irmandade, tudo.

- Ali, olha o bicho preto! Olha o bicho preto lá!

Olhá rapaz. Isso ai foi na baixa de 40 , na baixa da enchente..

Mas tinha que ser o tal de bicho preto.

Tinha que ser, eu mostrei pra ele, tudo.

Até agora nós conversemo essas coisa, eu e o Jorge, né.

Meus outros irmão já morreram. Conversemo.

Quando eu converso essas coisas com o Jorge, ele diz assim:

- Mas é mesmo, tinha que ser o tal de bicho preto.

E ele era grossinho, sabe?

Era um cavalinho, era um cavalinho.

Então contando pra mãe, eu chamei a mãe, chamei o pai.

Pra eles ver, mas não deu tempo, o troço corria muito.

De manhã, quando vinha clareando o dia.

De manhã,
Tudo bem.

Aí a mãe comȩ̣o a contar a história do bicho preto.

Aí a màe come⿻̧o a con
Que era um filho, né?

Que era um fillho, né?
Que era ruim pra mãe, botou a encilha dele na màe, montou a

Que era ruim pra

cavalo na màe, né?

Então nớs fiquemo naquela assim.
Nós escutando e a mãe contando aquilo.

Nós escutand

- Ô Jorge, era o tal de bicho preto, era um cavalinho.

Então essa estória eu queria contar pra vocês.

Hahahahaha! Hehe.

Eu queria contar essa estória.

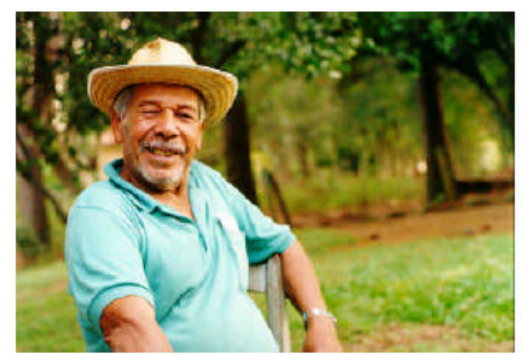

112

e

alegórico de seu discurso, ao contar não como as coisas são, mas com o que elas se 
assemelham e se relacionam ${ }^{3}$. Essa narrativa foi contada por Seu Adão no desenrolar de outras, em que era recorrente a presença de um mistério, na forma de um animal fantástico, uma luz, uma sombra, espíritos de escravos, mulheres de branco, moedas antigas, temporais, redemoinhos nas águas. Essas epifanias ${ }^{4}$ se manifestavam nas narrativas relacionadas a espaços do Arquipélago e tempos do cotidiano que são liminares entre o domesticado e o desconhecido, tais como o mato, as águas, os banhados, a noite e suas divindades e seres fantásticos. A figura do animal fantástico na narrativa retoma o gesto de re-fundação da comunidade nas ilhas após a enchente, em uma forma de relação com a natureza que não é certamente a tentativa de controle por parte da civilização industrial moderno-contemporânea dos recursos e ambientes naturais, mas a de inserção nessa paisagem e de aceitação dos desafios de seus ritmos cósmicos de morte e renascimento.

Ao trazerem a figura do pescador e do barqueiro que se lançam nas águas, do caçador, do "capineiro" e da benzedeira/bruxa que se embrenham na mata escura, essas narrativas falam de uma forma de conhecimento desses espaços e seus ritmos que é na verdade um reconhecimento das muitas "faces do tempo", dos saberes e fazeres dos antepassados que fundaram esse viver coletivo em meio às águas e os banhados, e que são retomados e reinventados em tempos de degradação ambiental e crescimento urbano, sob o desafio de fazer esse modo de vida durar. Não foi à toa que os momentos de cheia dos rios, que pude observar, eram os momentos em que essa identidade era reafirmada com mais força. Contrapondo-se às notícias de morte, doença e perda, o prazer dos ilhéus em falarem de outros "dilúvios" passados não deixava de trazer uma certa heroicidade ao narrador que hoje em dia, já espera por nova subida das águas, pela água que toma de volta "o que é dela", como diziam.

Para que emergissem nas narrativas essas "faces do tempo" era preciso, portanto, investigar de perto como alguns narradores contavam sua própria trajetória através dessas imagens. O narrador vale-se de um saber compartilhado por uma "comunidade narrativa"6 para interpretar sua trajetória, na medida em que o tempo de vida é transformado em "tempo pensado", , ou melhor, tempos pensados, na ação narrativa. Deslocar a análise sobre a narrativa oral e sobre a memória coletiva dos "conteúdos"

\footnotetext{
${ }^{3}$ Lévi-Strauss, 1996.

${ }_{5}^{4}$ Durand, 1988:15.

${ }^{5}$ Durand, 2001.

${ }^{6}$ Lagdon, 1999.

${ }^{7}$ Bachelard, 1988.
} 
que são narrados para o reconhecimento, na palavra do interlocutor, dessa "inteligência narrativa" de construir conhecimento sobre o tempo, para usar a expressão de Paul Ricouer $^{8}$, é a condição de que a entrevista com esses narradores se torne muito mais do que uma coleta de dados de um questionário, a fixação de relatos míticos na escrita ou mesmo algo além do que é proposto pela técnica de entrevista negociada, não-diretiva ${ }^{9}$ que é comum em pesquisas qualitativas. É esse reconhecimento que funda a relação de confiança no trabalho de campo entre o pesquisador e seus informantes. Não estávamos atrás de uma história impessoal, mas da história de cada uma dessas pessoas.

Quando questionados sobre as paisagens do Arquipélago e sua transformação, ao narrarem não apenas sua experiência, mas as estórias que ouviram de familiares e outros moradores, a lembrança evocava figuras míticas e lendárias que estavam presentes na memória coletiva do lugar, revelando uma estrutura simbólica para se pensar os itinerários dos grupos urbanos que foram se inserindo no contexto da cidade. Essa arqueologia dos tempos sobrepostos na paisagem do arquipélago não era algo subjacente, ou escondido nos relatos, mas, pelo contrário, os narradores sabiam que esse conhecimento que vai além de sua própria história de vida só podia ser acessado na relação que se estabelecia entre narrador e ouvinte, e na disposição para aderir às imagens que iam fazendo uma estória "puxar" ${ }^{10}$ a outra.

\section{$O$ registro da narrativa}

Após mapear e percorrer a rede social de alguns informantes, pude estabelecer um contato maior com pessoas que eram ao mesmo tempo reconhecidos pelos vizinhos, amigos e parentes como narradores do "tempo dos antigos", e igualmente acolheram a proposta de realizar algumas gravações em vídeo em torno do tema da memória e das estórias que, como diziam, tinham para "passar adiante". Dona Laci foi a pessoa com quem mais tive diálogos em torno da memória das ilhas. Retornei muitas vezes a sua casa, quando geralmente ela, um de seus 10 filhos e um de seus 48 netos se juntavam à

\footnotetext{
${ }^{8}$ Ricouer apud Eckert e Rocha, 2000:12.

${ }^{9}$ Thiollent, 1980.

${ }^{10}$ Para entender, então, o que dizem esses narradores, para "ouvir" essas estórias, então, em uma leitura como a que proponho aqui, é necessário "estar presente à imagem, no minuto da imagem" (Bachelard, 2000:01). Trata-se de adotar um método próprio do campo da expressão poética, ao centrar a atenção sobre a potência criadora das imagens que trazem esses narradores, sobre a "ressonância" dessas imagens na forma como se reúnem em torno de um pensamento central, na maneira como cada imagem e cada estória "chama" a seguinte. Para Bachelard, a imagem poética é semente que nos faz "criar o que vemos" (Bachelard, 1996:14), é "germe de um mundo", concebendo a imaginação como dinamismo organizador que "deforma as cópias pragmáticas fornecidas pela percepção" (Durand 2000: 30).
} 
conversa. Além de contarem e recontarem suas lembranças familiares, indicaram outros narradores e lugares a serem descobertos. Acabei optando então por quatro narradores, pela forma como narravam sua história de vida em meio a estórias, saberes e fazeres próprios do modo de vida na ilha "a caminho da cidade"

Dona Laci passou a infância na região do Delta do Jacuí, e só saiu "da roça", como diz, para casar com um pescador morador da ilha, quando então passou a trabalhar como lavadeira. Com a morte do marido, chegou a morar na margem urbana do rio, trabalhando como cozinheira em clubes esportivos na beira do Guaíba, até se aposentar aos 70 anos e então retornar à Ilha Grande dos Marinheiros. Dona Maria, de 68 anos, benzedeira e ex-empregada doméstica, veio da região da pecuária no RS, tendo morado em outras favelas da região metropolitana até parar nas ilhas. Adão, com 69 anos, viveu a passagem do trabalho rural na infância para o ofício de marceneiro naval na idade adulta, construindo embarcações para clubes esportivos, vivendo hoje como aposentado, na companhia de filhos e netos. Assim como Laci, Cláudio, um pescador de 58 anos conta sua vida com a marca da necessidade de atravessar as águas do Guaíba para ganhar o sustento, alternando o trabalho informal e o emprego no setor industrial com a prática da pesca.

De todos os narradores, Seu Adão foi certamente quem mais teve prazer e habilidade em colocar-se na figura do narrador. Desde o primeiro encontro assumia uma performance que exigia do ouvinte uma contrapartida. Ao encontrá-lo, conversava contando estórias, causos. Os netos costumavam se chegar para ouvir as suas estórias. A cada pergunta que fazíamos, por mais simples que fosse, Seu Adão fazia uma pausa, iniciava o relato de uma estória contando algum mistério, e interrompia a narrativa dizendo - “Mas depois eu não vou contar, hein?”. Era a combinação que fizemos várias vezes de um dia de gravação em vídeo, em que não apenas a minha presença, mas a de toda equipe de gravação era esperada por ele e pelos netos. Acabei realizando a entrevista sozinho, mas atendendo a sua reivindicação - a disponibilidade de tempo e a despreocupação com as horas. Câmera na mão, olho no olho de Seu Adão, gravamos mais de 5 horas intercaladas, nas quais ele assumia contente o personagem perante à esperada gravação. Enfatizava o plural, eram estórias que ele queria contar "pra vocês". Por vezes, via que buscava, com os olhos, mais algum ouvinte, quando estávamos a sós,

\footnotetext{
${ }^{11}$ Durham, 1984.
} 
demonstrando como estava habituado a contar suas estórias para uma platéia, e não para uma pessoa só.

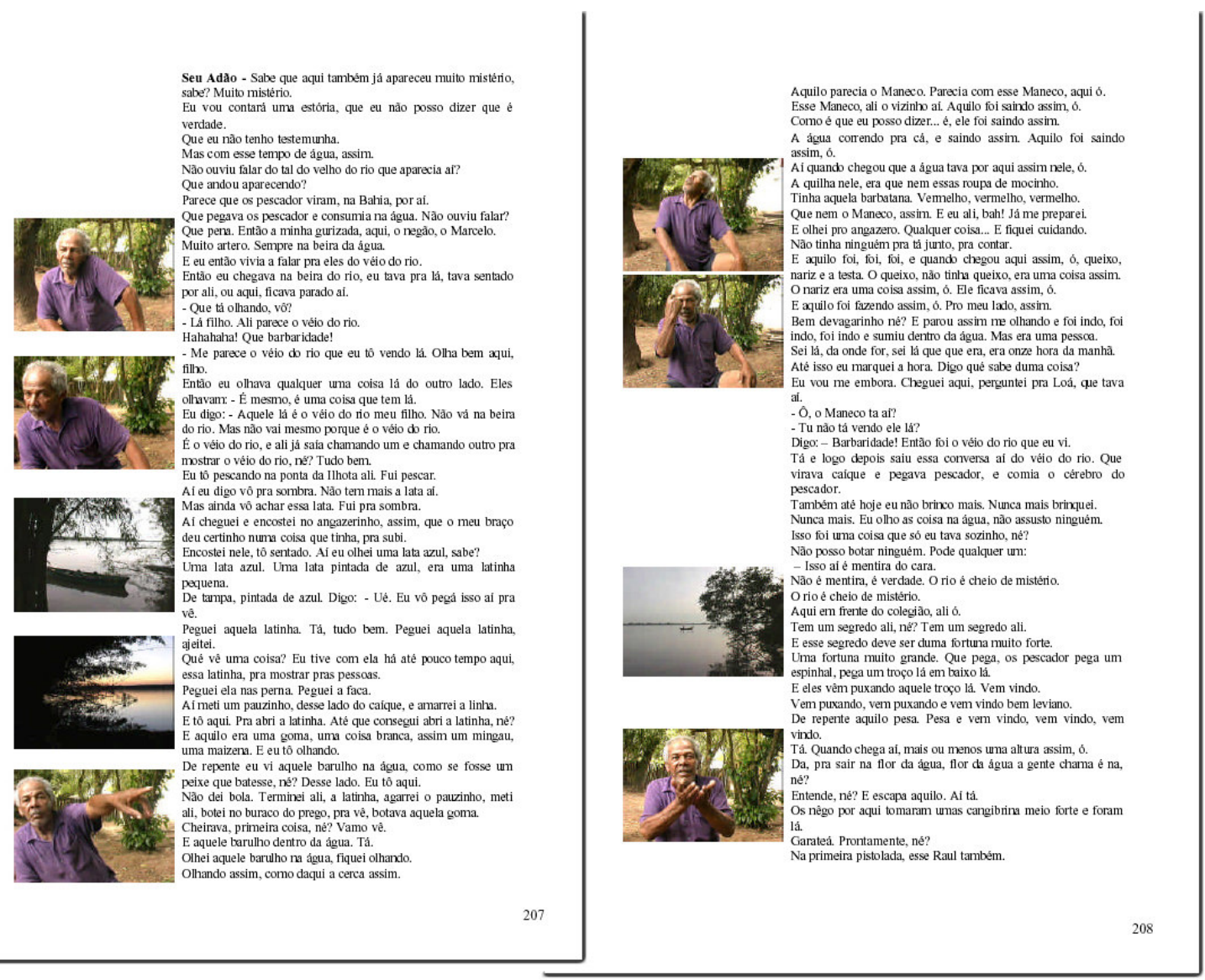

Nessa situação de performance, a situação de gravação se tornava uma forma de evento narrativo ao estabelecer a interação entre sujeito narrador e seus ouvintes. $\mathrm{O}$ uso do vídeo possibilitou uma maior aproximação da "arte de dizer"12 do narrador, das suas táticas de entonação de voz, de orquestração dos silêncios, da cadência dos gestos que faziam com que a estória fosse contada com todo o corpo. Por ter passado muitas horas ouvindo essas estórias, na companhia de outros ouvintes, sem a câmera, eu havia aprendido a participar do evento narrativo e provocar muitas vezes a "ocasião", a que se refere De Certeau, em que o relato toma forma ${ }^{13}$. Ao questionar os narradores sobre as marcas presentes na atual paisagem da região (o nome dos lugares e a sua forma - uma casa abandonada, uma estrada, uma embarcação) os significados relacionados a tais lugares eram evocados na forma de um "buraco no tempo", uma ausência de sentido

\footnotetext{
${ }^{12}$ De Certeau, 1994:160.

${ }^{13}$ De Certeau, 1994:158.
} 
que era evocada na forma de um vestígio ${ }^{14}$, conforme De Certeau, um "ali" que a mão, os olhos, a postura corporal apontavam, aliados às palavras que faziam então uma recostura do tempo, nas lembranças de como o narrador tomou conhecimento de tais significados, inserindo nesse "ali" um "assim", os muitos gestos e práticas que estavam inscritos nessa paisagem e que só o narrador e seus ouvintes poderiam acessar na situação da narrativa.

Seguindo alguns esquemas de De Certeau, teríamos então esses "golpes" da memória que mediatizam transformações espaciais e "fazem ver" aquilo que até então era invísivel, um tempo outro inscrito no lugar:

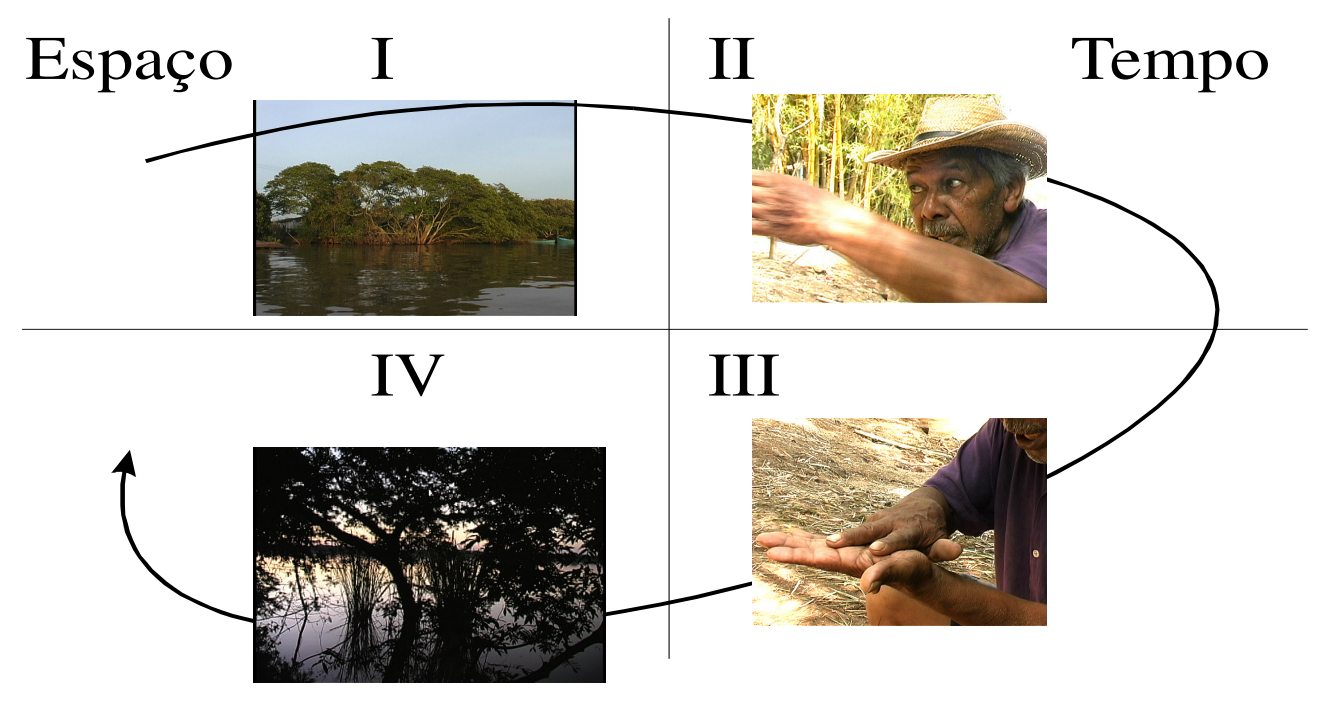

Esses golpes são as surpresas na narrativa, as reviravoltas, que precisam da contrapartida dos efeitos da narrativa no ouvinte. Essa contrapartida do ouvinte é devolvida ao narrador não só na palavra, nas perguntas e nas interpretações que o ouvinte faz sobre o que o narrador conta, mas igualmente ela é feita com o corpo, na forma como corporalmente acompanhamos a figura do narrador, como centramos os olhos e ouvidos nos seus gestos e assim temos condições de referirmo-nos, também, a esse outro lugar evocado na narrativa, que está ao mesmo tempo ausente e no entanto presente na forma como o narrador se situa na relação espaço e tempo. Esses outros tempos e lugares estão projetados então, em relação a narrador e ouvinte, numa

\footnotetext{
${ }^{14}$ De Certeau, 2002:215.
} 
dimensão que é vivida corporalmente, situada em relação aos espaços cotidianos do narrador.

Seu Adão, por exemplo, tinha o seu "banco de praça" preferido, um toco de madeira colocado entre a beira do rio e a estrada que atravessa essa margem da ilha, onde ele costuma se sentar para conversar e contar estórias para seus netos e amigos. Nesse lugar, Adão tinha de um lado as águas e as demais ilhas para as quais se referia em determinados momentos, interrompido pelas embarcações que passavam e muitas vezes "carregavam" o relato à bordo, para as muitas aventuras de Adão atravessando os canais do Delta. Do outro lado, Adão tinha a sua casa e seu quintal, envoltos pelo mato da ilha onde muitos seres fantásticos se manifestavam nas narrativas. E cortando esses espaços, a estrada que conduzia a narrativa para a vila, a ponte e a cidade, e as aventuras de Adão em sua trajetória na cidade. A própria casa de Adão está centrada em meio a esse universo que a narrativa desvela, da janela de sua casa, enxergava o rio e os barqueiros que acenavam ao passarem, enquanto que da varanda contemplava então o movimento da ilha.

Gravar em vídeo, tentando evocar essa relação entre tempo e espaço feita pelo narrador, traz portanto o desafio de expressar na dimensão plana, bidimensional da tela do vídeo, a profundidade espacial e temporal que esses "golpes" do narrador encerram. Essa relação do cenário, do personagem e do fluxo da narrativa é uma questão central para o Cinema, na forma de construção da narrativa cinematográfica, consagrada nos filmes de faroeste norteamericanos em que a figura do herói é engrandecida em relação à paisagem deserta do oeste. É uma relação que não é estabelecida em um plano só (ou um quadro só), mas que precisa da articulação de diferentes planos que formem uma sequência. Quando se tem a articulação desses planos de forma que sua estética visual e o sentido que expressam se encontram para passar uma mensagem, tem-se o que é definido como uma "decupagem"15. A busca de uma forma de enquadrar a figura do narrador para inseri-la então numa decupagem junto às imagens dos espaços das ilhas, era para mim não apenas um problema de representação, mas a condição da interpretação do fenômeno investigado, essa relação narrador/ouvinte/cenário, que podia ser percebida no trabalho de campo, cuja análise permitia não apenas uma melhor operação da câmera de vídeo (nas escolhas do que enquadrar e como, de como mover a câmera ou mudar de ponto de vista) mas igualmente orientava a própria postura em

\footnotetext{
${ }^{15}$ Aumont, 1993; Amiel 1997; e Gardies, 1993.
} 
campo e as provocações a serem devolvidas ao narrador. Orientava também as escolhas da montagem, para que a imagem do gesto do narrador "continuasse" na imagem seguinte, em planos dessa paisagem, dos lugares aludidos.

André Gardies pensa a relação como tempo e espaço são estetizados no Cinema, através de uma relação que o espectador irá estabelecer com o espaço diegético (que é revelado pela narrativa) mediada pela relação física que este estabelece com a tela do cinema, ao voltar olhos e ouvidos para esta, e tomar as referências da tela (à frente, à esquerda, atrás) como ponto de partida para imaginar-se dentro do mundo do filme. Apropriando-me de alguns esquemas de André Gardies ${ }^{16}$ sobre a narrativa cinematográfica, poderíamos dizer que a forma de enquadrar o narrador no vídeo precisa levar em conta as seguintes dimensões, para articular a relação tempo/espaço proposta por De Certeau:

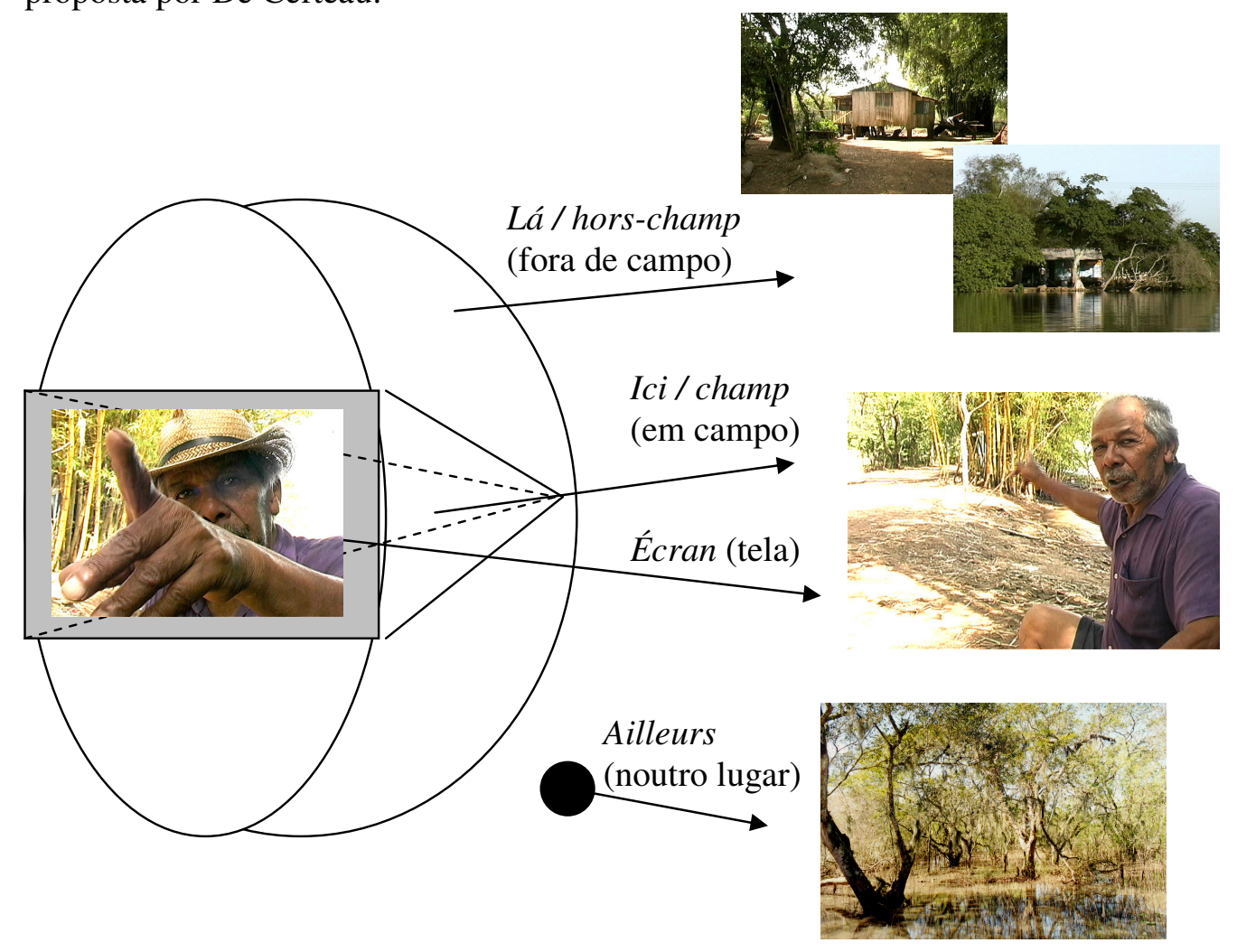

O que é projetado na tela (écran), evoca uma ação que ocorre no espaço tridimensional, articulando o campo (champ) visível da tela (Ici), com aquilo que o espectador não vê, mas por ser sugerido ele sabe que está ali $(L a ̀)$, fora do campo visual (hors-champ), como a casa de Adão, o rio, a estrada ou mesmo o pesquisador/ouvinte que está atrás da câmera a quem a voz e os gestos do narrador são endereçados.

\footnotetext{
${ }^{16}$ Gardies, 1993.
} 
Finalmente, os lugares e tempos a que o narrador se refere encontram-se numa dimensão que não é contígua a esse campo visual, mas que mesmo estando além (ailleurs), em outro lugar, só é imaginável pelo que é visto e ouvido em campo, pelo que a ação contida no quadro permite evocar.

Na página da dissertação, essa relação foi colocada através de uma edição da fala do narrador, transposta para a escrita, de forma a evocar o ritmo da oralidade, do som da palavra dita, na forma como o ritmo de leitura é proposto, ou seja, em uma forma mais próxima da poesia de operar a sucessão de frases e repetições de jogos verbais. Já as imagens dos gestos, olhares e posturas, postas em sequências em conjunto com imagens da paisagem, foram postas em um mesmo canto da página, para darem a idéia de sucessão, em que espaços em branco foram sendo deixados como forma de aludir a elipses temporais ${ }^{17}$ e mudanças de direção do relato que criam a possibilidade de referência a esses lugares da memória.

É esse outro lugar, instaurado pelos "golpes" da narrativa, pelas rupturas colocadas pelo mundo da memória, que no momento oportuno, modifica a própria organização do visível e revela então a paisagem do Arquipélago de uma outra forma, enquanto "espaço fantástico"18 da memória. Representar esses lugares a partir do ponto de vista que os relatos traziam, era então um novo desafio, o de olhar para o Arquipélago da forma como os narradores propunham.

\section{Representando a paisagem}

Não apenas ouvindo as narrativas, mas igualmente acompanhando algumas práticas cotidianas desses narradores, pude começar a perceber uma outra paisagem do Arquipélago. $\mathrm{O}$ conceito de paisagem que orientou essa mudança de perspectiva é a paisagem como a entende Simmel $^{19}$, um corte na continuidade infinita do espaço, promovido pela Cultura, uma forma que se materializa e organiza-se sensivelmente, expressando as vontades humanas com relação ao espaço. A paisagem não se esgota portanto na maneira de perceber o espaço, mas igualmente, na materialização da

\footnotetext{
${ }^{17}$ As elipses temporais são a alusão a tempos na narrativa fílmica que não são mostrados, mas apenas sugeridos ao espectador na continuidade das ações evocadas pelas sequiências de imagens. Cf. Aumont, 1993.

${ }^{18}$ Durand, 2001 e Eckert e Rocha, 2000.

19 "Para nós, e só para nós, as margens do rio não são apenas exteriores uma à outra, mas 'separadas', e a noção de separação estaria despojada de sentido se não houvéssemos começado por uni-las, nos nossos pensamentos finalizados, nas nossas necessidades, na nossa imaginação. (...) A ponte se integra à imagem da natureza, numa relação mais estreita com as margens ligadas.” (Simmel, 1996:11-12)
} 
vontade humana com relação ao espaço, na maneira como uma ponte, uma estrada, uma casa, um cais ou uma cerca vão compondo formas sensíveis. As paisagens são o arranjo desses elementos, que dão forma aos gestos de unir, separar, atravessar, fechar, ou adentrar os espaços, por exemplo. Da mesma maneira, o entendimento do ambiente como ambiente técnico-cultural, conforme Leroi-Ghouran ${ }^{20}$, é central para entender como os gestos presentes às práticas cotidianas desses narradores, e as muitas ações narradas dos "antigos" nesses espaços, são a chave para compreensão do Arquipélago como ambiente habitado, praticado.

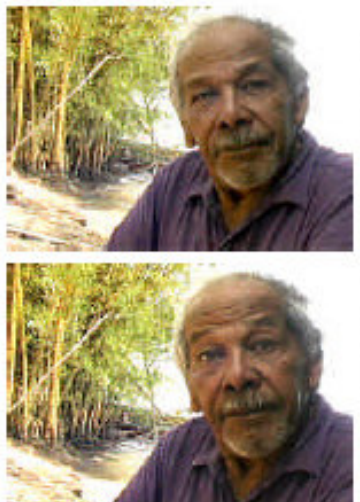

Seu Adâo - Ah é. A Ilha do Lobisomem. Ali tem um pé de angazero muito velho, né? Muito velho. E é muito assombrado ali.

A Illha do Lobisomem é ilha assombrada mesmo, assombrada. Mas o pessoal para ali, tudo. Sempre vinha desconfiança.

Por fïm já não é mais assombro, è a desconfiança, né?

Sei lá, a imaginaçâo, a pessoa já vê as coisa.

Tudo bem. Fomo caça capivara. Eu e o immào.

O Irmào é o Raul, eu chamo ele o Irmào. Toquemo pra lá.

Trepamo em cima da árvore. Daqui a pouco. Eu falei pro Irmão: - Ó Irmão, vem o bicho aí.

- Será Seu Adão?

Digo - É. Escuta só.

Aquilo vinha quebrando tudo, né? Tá bem.

Ai eu gritei pra ele: - Fica quieto.

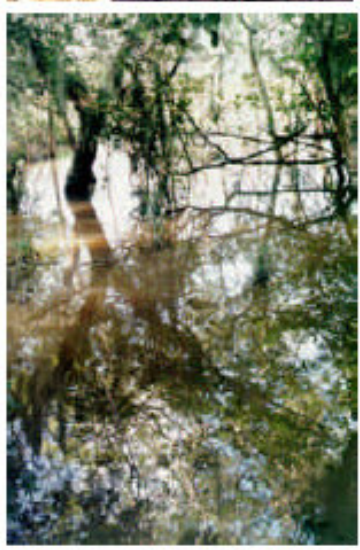

Rapaz de Deus, eu sentado, tava altinho assim.

E era un boi. Era um boi branco.

Eu quebrava os galho de pau, quebrava os toco, atirava nele, ele sóó aparava na guampinha.

O Irmào: - Tá brincando, seu Adão?

Ele tava longinho de mim, né?

Digo: - Brincando o quễ rapaz, tem um baita dum boi aqui!

Diz ele: - Mas não é o bicho?

- Não, é um boi, vem cá vê.

E agora? E agora pra descê de lá pra vim cá?

Ai eu disse pra ele:

- E agora como é que eu vô fazê, como é que eu vô descé aqui?

Não podia fazer nada, mas não tinha, não tinha boi, nào tinha nada, nào tinha ninguém ali. Ai se sumiu, parou o troço.

Agarrei disse: - Ô Irmào, encosta ligeiro aqui, vamo descê aqui.

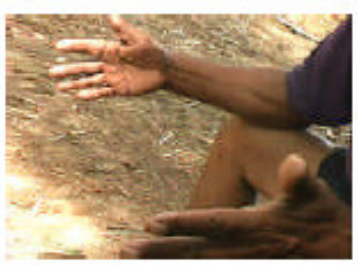

Tinha uma borboleta. Olha, não vou exagerar, tchê!

Mas ela tinha as asa desse tamanho, assim.

Aquele bicho vaando de baixo de mim, assim.

Ah, rapaz. Começou a me dar um nervoso.

Comepou a me dar um nervoso ai eu digo:

- Ó irmão, apura duma vez aí ó.

- O senhor nunca foi de se assustar, Seu Adào?

Aquele bicho ia lá rapaz. Aquele bicho fazia vento em mim assim, rapaz. E ele viu bem onde é que tava o bicho, né?

Tá. Tudo bem. Encostô, viemo embora.

Ai no otro dia foi pros Morrete. O Raul aí.

${ }^{20}$ Leroi-Ghouran, 1964. 
É essa paisagem outra que era preciso perseguir, e a melhor forma de fazê-lo era ensaiar a sua representação, com o uso da fotografia, e principalmente do vídeo, em momentos do trabalho de campo em que me aventurava pelos matos, banhados e margens das ilhas, acompanhado dos narradores, ou apenas de suas vozes e narrativas na lembrança, para tentar ver essas possibilidades de retornos desse "tempo dos antigos" que a sua narrativa inseria, modificando esses espaços. Luciana Hartmann, em uma etnografia sobre "contadores de causo" na região do Pampa gaúcho ${ }^{21}$, faz uma análise da relação entre a performance corporal do narrador, suas práticas cotidianas no campo e a forma da paisagem do Pampa, a planície, mostrando como o narrador, com gestos largos e olhos no horizonte tomava conta desse cenário em suas narrativas. Nas ilhas, pude ver como as narrativas traziam esse componente de uma forma muito particular de conhecer os espaços das ilhas, se embrenhando nos mistérios da mata fechada, na luminosidade das águas cercadas por vegetação. Essa narrativa de Adão é significativa de como a prática da caça "assombrada" do tatu e da capivara, feita à noite, em meio a vegetação fechada dos matos e banhados, insere-se numa paisagem noturna, plena de sons, seres fantásticos e luzes que são associados às manifestações sobrenaturais.

Há nessas narrativas a manifestação de um mistério em meio às paisagens, que podemos chamar de "epifania", ao seguirmos uma concepção simbólica da imaginação para o estudo da memória. O símbolo, para Gilbert Durand, tem o caráter de "epifania", aparição do indizível, de um significado que é inacessível diretamente à consciência: "O símbolo é, portanto, uma representação que faz aparecer um sentido secreto; ele é a epifania de um mistério" ${ }^{22}$. Nas narrativas a água, por exemplo, não está associada a um único significado. Como Bachelard já apontara ${ }^{23}$, a água pode tanto remeter a um sentido terrível e ameaçador (como nas enchentes), quanto pode remeter ao seu caráter fecundo e protetor. Logo, a imagem é simbólica, fazendo com que "para a consciência humana, nada seja simplesmente apresentado, mas tudo seja representado" ${ }^{24}$. Para interpretarmos, então, essa paisagem que se desenha nas narrativas, é preciso não se deter em uma imagem apenas, mas seguir a dinâmica das imagens, nos seus desdobramentos em que uma imagem vai levando a outra, convergindo esses elementos que compõe a paisagem para uma "constelação de imagens", organizadas no tempo, em uma linha narrativa.

\footnotetext{
${ }^{21}$ Hartman, 1999.

22 Durand, 1988:15.

23 Bachelard, 1998.

${ }^{24}$ Cassirer apud Durand, 1988:59.
} 
Desse ponto de vista, as estórias das ilhas não poderiam ser interpretadas como narrativas importadas de um folclore historicamente localizado, como "herança açoriana" conforme as enquadrada uma memória oficial da cidade. Essas narrativas são uma composição inteligente de figuras míticas e lendárias que surgem na interpretação das muitas heranças da formação de uma civilização urbana no sul do Brasil ${ }^{25}$. As estórias que contam de tesouros enterrados, de "assombros" nas águas e matas, de animais fabulosos, de bruxas e lobisomens revelam o "dinamismo das formas" 26 nas representações imaginárias dos narradores em seus saberes singulares, apresentando uma "imagem do mundo" 27 que ordena os elementos do cosmos, como as águas, o mato, os animais, os homens e as mulheres de forma a retomar o gesto de fundação de seu viver coletivo à beira das águas do Lago Guaíba.

\subsection{Seu Cláudio}

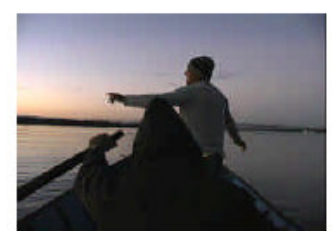

u vinha no barco. Vinha no barco.

Vinha eu e um irmão meu, né?

E como tem esse pinheiro lá pra cima, saiu de perto da

figuera assim.

Umas onze a doze bola de fogo assim que subia

Subia, era até un dis de vento leste muito fote.

E eu vi aquilo e meu irmõo ia remando de costa pra

aquilo eu ia de frente, né na popa sentado, ai asa

aquilo e eu ia de frente, ne na popa sentado, aí assim eu

disse pra ele:

- Paulo, Paulo lá, olla lá, olha aquilo al

Um monte de bola de fogo saindo assim, tipo um liquinho aceso assim, entendeu?

Bem forte e se desmanchava no ar.

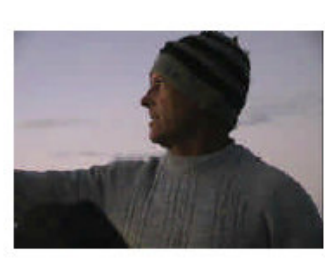

E... muitos diziam que ali tinha ouro.

Acho que ouros ali.

Aí no outro dia.

(...) na outra terça eu fui lá mais aí a lua tava muita

clara, né? Fui lá a pé, fui a pé pra olhar.

Se de repente tem oro enterrado ai vamo cavar, né?

E a figuem tá lá, a figuera ainda nà sei se é

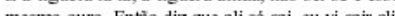

Uma, tipo uma, unna pessoa de branco, uma mulher de

branco saia assim. Passava pela, cruzava.

Saia dali e passava pro outro lado assim, olhando pra

gente.

Um monte de gente diz que tem os escravo ali.

Tinha uma casa que embaixo tinha um porão e tinha

até corrente pra amarrár os escravo.

E. Muitas coisas eu já vi assim, né?

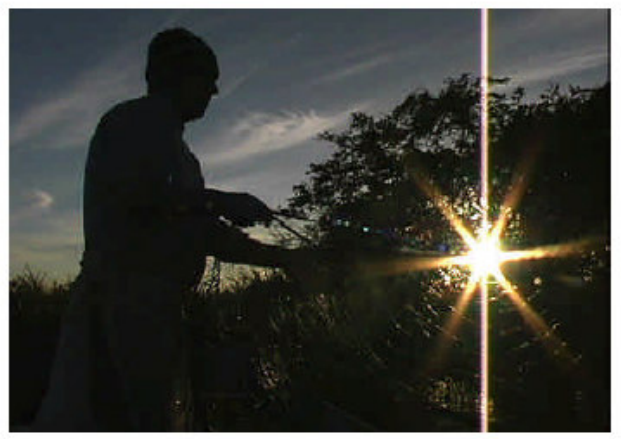

${ }^{25}$ Rocha, A.C., 1994.

${ }^{26}$ Durand, 2001:41

${ }^{27}$ Leori Gourhan, 1965. 
Representar na imagem fotográfica, ou em sequências de imagens e sons no vídeo, essa paisagem enquanto "espaço fantástico" da memória é portanto um desafio para a realização da etnografia que não se encerra na representação para um outro (o leitor) a forma dessa paisagem. Era preciso conseguir ver no ambiente do Arquipélago esse dinamismo das formas ${ }^{28}$, a sua "poética do espaço"29 enquanto morada de águas, aderir às imagens das raízes e galhos que se redobravam, se contorciam e reviravam a terra e a água, como são narradas nas narrativas de tesouros enterrados.

Era preciso ver nas águas calmas dos rios a possibilidade de suas ondulações assumirem a correnteza terrível que os narradores contavam ao falarem de naufrágios, era preciso ver nesse ambiente a sua característica mais fantástica que é justamente a sua característica ecossistêmica: a sua permanente mudança, na medida em que as águas "devoram" os terrenos das ilhas nos períodos de cheia e trazem consigo novas formas de vida entre a terra e água, que dão lugar a outras formas com a descida das águas. A expressão dos ilhéus de que "as ilhas de movem" é significativa dessa constante mudança de suas margens e ambiências.

Seguindo outro esquema de De Certeau, sobre a possibilidade de uma "hermenêutica do Outro" ${ }^{, 30}$ no exercício etnográfico, teríamos então esse movimento do antropólogo, com o objetivo de interiorizar imagens que lhe são fornecidas pelo narrador para então poder representá-las na linguagem ${ }^{31}$. Ainda que as imagens produzidas pelo antropólogo permaneçam dentro dos limites do "mesmo", como coloca De Certeau, dentro do que a linguagem possibilita, do que as estéticas da fotografia, do vídeo e mesmo da página composta de texto e imagem comportam, há essa evocação dessa epifania, dessa convergência de imagens que não pode ser aludida em uma imagem apenas, mas na sucessão de imagens sonoras e visuais que vão novamente representando a etnografia como uma narrativa que "ondula" no tempo do fio narrativo:

\footnotetext{
${ }^{28}$ Rocha, A.C., 1995.

${ }^{29}$ Bachelard, 2000.

${ }^{30}$ Refiro-me a um estudo que Michel De Certeau realiza sobre os escritos de Jean De Leris, interpretando o movimento realizado no trabalho de escrita da palavra do Outro, os grupos indígenas brasileiros que o viajante e religioso europeu descreve. Apesar da inevitável deformação da palavra nativa pelo olhar do estrangeiro e pela forma final da linguagem escrita ("O MESMO" no esquema gráfico), algo da alteridade permanece, uma fala outra, cuja escuta já não está mais no plano do mundo selvagem, mas no mundo do OUTRO. De Certeau, 2002:215.

${ }^{31}$ Eckert e Rocha, 2000b.
} 
Seu Cláudio - Nós saía da Ilha da Conga lá pra Rua do Parque, lá. (...) Naquele tempo, quando eu era guri, não tinha o cais ali.

Então o barco entrava ali e ia lá na Voluntários, nosso barquinho. Então nós ia lavar casa de família, esfregar o chão.

Ia lá pra pegar as coisas que nós ganhava das famílias, pra levar pros outros tios lá na Ilha.

Nós acendia o fósforo para clarear o barco no rio, escuro de noite. Bah! Um trabalhão, passemo.

Eu que sei o que minha mãe passou, muito trabalho.

E os barcos lá, pegando nós, no meio do rio.

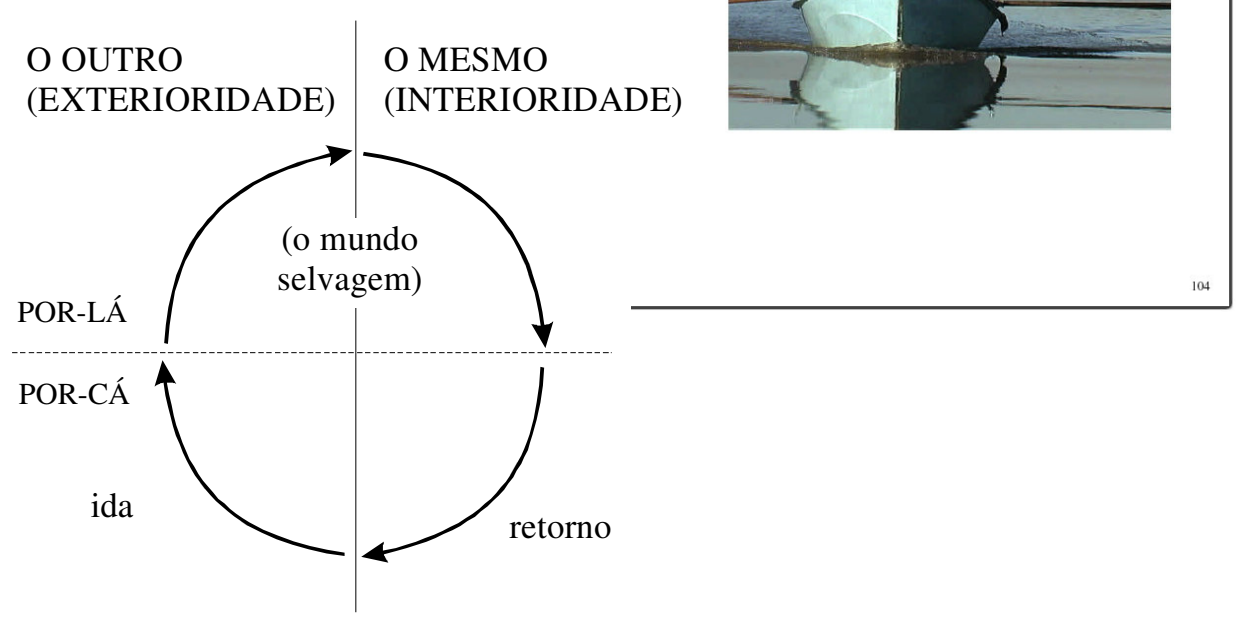

Esse movimento só é possível, por parte do antropólogo, se entendemos que o próprio narrador realiza esse movimento em sua interpretação do tempo, para poder justamente pensar o tempo. Ao mergulhar na sua experiência temporal, não são as ações e fatos que o narrador reconstitui, mas os seus significados, as suas "razões para durar" ${ }^{\prime 2}$. As narrativas de suas trajetórias sociais no ambiente urbano de Porto Alegre trazem esse componente heróico de uma experiência na cidade que é marcada pela duração de um viver coletivo na paisagem micro-cósmica das ilhas. Os gestos de travessia, de entrada e saída da cidade pelas águas são arranjados pelas práticas cotidianas da pesca, da extração de lenha, capim e também da catação e separação do lixo trazido da cidade e separado para vender de volta à cidade. Através destes gestos, a paisagem dos banhados e das águas das ilhas vai ganhando esse contorno liminar, entre

\footnotetext{
${ }^{32}$ Bachelard, 1988.
} 
o espaço doméstico dos ilhéus e o espaço construído da cidade, um ambiente ameaçador, uma natureza que sempre pode retomar "o que é seu", mas ao mesmo tempo um refúgio, uma paisagem que sempre oferece a possibilidade de recomeçar.

Entender, dessa forma, a arte de moldar a "matéria do tempo", é realizar uma "etnografia da duração" "33, conforme os termos propostos pelas antropólogas Cornelia Eckert e Ana Luiza Carvalho da Rocha. As autoras incorporam as contribuições de Gaston Bachelard e Gilbert Durand ${ }^{34}$ que investigam o fenômeno da lembrança enquanto pensamento sobre o tempo e suas durações, em todo seu dinamismo criador. Compondo a obra da dialética da duração, Bachelard percebe a duração como ritmada por "tempos vividos" e "tempos pensados", onde recordar é uma atividade de acomodar, nas razões do tempo presente, as experiências narradas de um passado vivido e pensado. Para Bachelard a lembrança não é apenas uma versão do passado que as "comunidades afetivas" tenderiam a compor no trabalho da lembrança, conforme Halbwachs ${ }^{35}$, pois "a continuidade da duração não se apresenta como um dado imediato, mas como um problema" 36 . O "tempo pensado", para Bachelard, constitui-se na ordenação, ou na “ondulação" de uma série de rupturas ${ }^{37}$ com a continuidade do tempo. O narrador estabelece uma hierarquia de ações, uma cadeia de gestos, de escolhas desenhadas no tempo. A narrativa trata de colocá-los em ritmos, fazê-los ondular.

O "trabalho" da memória é então, o de contar, premeditar, romancear o tempo, atividades que, conforme Gilbert Durand remetem à função fantástica da imaginação em organizar esteticamente a recordação a partir de fragmentos vividos. A memória não é pois "intuição do tempo" que passou, mas a sua negação, estetizando a possibilidade do tempo durar ${ }^{38}$. Às faces do tempo que corre sem cessar, em direção à morte dos indivíduos e dos grupos sociais, a memória acrescenta a possibilidade de regressar, de

\footnotetext{
${ }^{33}$ Eckert e Rocha, 2000:11

${ }^{34}$ Ver Bachelard, 1988, 1996, 1998, 2000. e Durand, 1988, 1998, 2000, 2001.

${ }^{35}$ Halbwachs toma a continuidade da existência como um dado, e portanto, mantêm a noção de tempo como o inevitável fluxo do futuro, que se torna presente para virar passado. Trata-se de uma observação que realiza Jean Duvignaud, em seu prefácio à obra “A Memória Coletiva” (Halbwachs, 1990:15).

${ }^{36}$ Bachelard, 1988:07

37 "Quando queremos falar de nosso passado, ensinar a alguém como é nossa pessoa, a nostalgia das durações em que não soubemos viver perturba profundamente nossa inteligência historiadora. Gostaríamos de ter um contínuo de atos e de vida para contar. Mas nossa alma não guardou uma lembrança fiel de nossa idade nem a verdadeira medida da extensão de nossa viagem ao longo dos anos; guardou apenas a lembrança dos acontecimentos que nos criaram nos instantes decisivos do nosso passado. (...) Nossa história pessoal nada mais é assim que a narrativa de nossas ações descosidas e, ao contá-la, é por meio de razões, não por meio da duração, que pretendemos dar-lhe continuidade".(Bachelard, 1988:39)

38 “... a memória permite um redobramento dos instantes e um desdobramento do presente; ela dá uma espessura inusitada ao monótono e fatal escoamento do devir, e assegura nas flutuações do destino a sobrevivência e a perenidade de uma substância." (Durand, 2001: 402)
} 
regredir, de repetir. Neste sentido, a narrativa é fundamental para inserir, no próprio "fio" temporal do discurso, os retornos dos fragmentos do vivido humano.

Ao aderirem a essa dimensão fabulatória da memória, desvela-se um "mundo",39 aberto pela narrativa, enquanto uma "forma de olhar" para este, enquanto uma forma de conhecê-lo, conforme ganha significado pelas imagens encadeadas pelas narrativas, por seu caráter simbólico. É por isso que a memória das ilhas é narrada em meio a um repertório de contos, lendas e narrativas de caráter mítico, que encontram, na dinâmica das imagens do tempo que as narrativas organizam, uma forma de fazer durar os gestos e os saberes do "tempo dos antigos" na paisagem presente.

Para investigar esse fenômeno da memória, portanto, não há outra forma ${ }^{40}$ senão aderir a essa dinâmica das imagens, mergulhar nas imagens em que o próprio narrador se deixa navegar, para encontrar as suas razões para durarem na paisagem do mundo contemporâneo. O uso do vídeo foi privilegiado nessa pesquisa, portanto, não só pelas vantagens que oferece em termos do registro audiovisual, de repetição dos fragmentos de gestos e palavras dos narradores, mas como uma forma do antropólogo mergulhar na figura do narrador, e se descobrir também no"nobre lugar de construção do conhecimento de si a partir do testemunho legado pelo Outro" ${ }^{\text {41 }}$.

Retomando, portanto, o que afirmam as antropólogas Ana Luiza Carvalho da Rocha e Cornelia Eckert, no artigo que inspirou o presente, acrescentaria a capacidade do uso do vídeo de levar os relatos e as imagens das narrativas produzidas em campo para o "meu pessoal", como diziam os narradores das ilhas, estendendo esse encontro etnográfico não apenas para os espectadores possíveis, mas certamente para a própria tradição de conhecimento a que se filia o antropólogo.

\section{REFERENCIAS}

AMIEL, V. Esthétique du montage. Paris, Nathan, 1997.

ATLAS AMBIENTAL DE PORTO ALEGRE. Coord. Rualdo Menegat, Maria Luiza Porto, Clóvis Carlos Carraro e Luís Alberto Dávila Fernandes. Porto Alegre, Editora da Universidade/UFRGS, 1998.

AUMONT, J. A imagem. São Paulo, Papirus, 1993.

BACHELARD, Gaston. A dialética da duração. São Paulo, Editora Ática, 1988.

BACHELARD, Gaston. A Poética do Devaneio.. São Paulo, Martins Fontes, 1996.

BACHELARD, Gaston. A Água e os Sonhos. São Paulo, Martins Fontes, 1998.

\footnotetext{
39 “Aquilo de que importa apropriar-se é o sentido do próprio texto, concebido de um modo dinâmico como a direção do pensamento aberta pelo texto. O poder de desvelar um mundo, que constitui a referência do texto". (Ricoeur 1976:104)

${ }^{40}$ Cf. Rocha, A.C., 1995.

${ }^{41}$ Eckert e Rocha, 2004:411.
} 
BACHELARD, Gaston. A Poética do Espaço. São Paulo, Editora Ática, 2000.

BENJAMIN, Walter. Obras Escolhidas III- magia e técnica, arte e política. São Paulo, Brasiliense, 1994.

BOSI, Ecléa. Memória e sociedade. Lembranças de velhos. São Paulo, Queiroz ED. Ltda. e EDUSP, 1987.

BOURDIEU, P. A Ilusão Biográfica. In: FERREIRA, M. e AMADO, J. (org.) Usos \& Abusos da História Oral. RJ, Fundação Getúlio Vargas, 1996.

OLIVEIRA, R. C. O Trabalho do Antropólogo. Brasília : Paralelo 15; São Paulo Ed. Unesp, 2000.

CERTEAU, Michel de. A Invenção do Cotidiano - 1: Artes de Fazer. Petrópolis, Vozes, 1994.

CERTEAU, Michel de. A Escrita da História. Rio de Janeiro, Forense-Universitária, 2002.

DEVOS, Rafael. Uma Ilha Assombrada na Cidade: Cotidiano e Memória Coletiva a partir das narrativas de antigos moradores da Ilha Grande dos Marinheiros, Porto Alegre, RS. Dissertação de Mestrado. PPGAS-UFRGS, Porto Alegre, 2003.

DURAND, Gilbert. Science de l'homme et tradition. Le nouvel esprit anthropologique. Paris, Berg International, 1979.

DURAND, Gilbert. A imaginação simbólica. SP, Cultrix, 1988.

DURAND, Gilbert. O imaginário. RJ, Difel, 1998.

DURAND, G. As Estruturas Antropológicas do Imaginário. São Paulo, Martins Fontes, 2001.

DURHAM, Eunice Ribeiro. A caminho da cidade : a vida rural e a migração para São Paulo. 3. ed. São Paulo: Perspectiva, 1984.

ECKERT, Cornelia e ROCHA, Ana Luiza Carvalho da. "Imagens do tempo nos meandros da memória: por uma etnografia da duração”. In: Koury, Mauro G P. (org.). Imagem e Memória: Estudos em Antropologia Visual. Rio de Janeiro, Garamond, 2000c.

ECKERT, Cornelia e ROCHA, Ana Luiza Carvalho da. A interioridade da experiência temporal do antropólogo como condição da produção etnográfica. Iluminuras: Série do Banco de Imagens e Efeitos Visuais, número 13. Porto Alegre: BIEV, PPGAS/UFRGS, 2000b.

ECKERT, Cornelia; ROCHA, Ana Luiza Carvalho. A memória como espaço fantástico. Iluminuras: Série do Banco de Imagens e Efeitos Visuais, ${ }^{\circ}{ }^{2}$. Porto Alegre: Banco de Imagens e Efeitos Visuais, PPGAS/UFRGS, 2000c.

ECKERT, C. ; ROCHA, A. L. C. . O antropólogo na figura do narrador. Revista Habitus, Instituto Goiano de Pré-História e Antropologia, Universidade Católica de Goiás, Goiania, v. 1, n. 2, p. 395-420, 2004.

ELIADE, Mircea. Mito do eterno retorno. SP, Mercuryo, 1992.

ELIAS, Norbert. Os Estabelecidos e os Outsiders. Rio de Janeiro, Jorge Zahar Editor, 2001.

GARDIES, A. L'espace au cinéma. Paris, Méridiens Klincksieck, 1993

GARDIES, A Le récit filmique. Paris, Hachette, 1993b.

GEERTZ, C. A Interpretação das Culturas. Rio de Janeiro, Zahar, 1979.

HALBWACHS, M. A Memória Coletiva. São Paulo, Vértice, 1990.

HARTMANN, L. Oralidade, Corpo e Memória entre Contadores e Contadoras de Causo Gaúchos. In: Horizontes Antropológicos, ${ }^{\circ} 12$. Porto Alegre, PPGAS-UFRGS, 1999. 
LANGDON, J. A fixação da narrativa: do mito para a poética de literatura oral. In: ECKERT e ROCHA (Org.). Revista Horizontes Antropológicos 12. Porto Alegre: UFGRS, 1999.

LEROI-GOURHAN, A. La geste et la parole. La mémoire et les rythmes. Paris, AlbinMichel, 1964.

LEROI-GOURHAN, A. La geste et la parole. Technique et Langage. Paris, AlbinMichel, 1964.

LÉVI-STRAUSS. Antropologia Estrutural. Rio de Janeiro, Tempo Brasileiro, 1996.

PARQUE ESTADUAL DELTA DO JACUÍ - PLANO BÁSICO. Vol. 1 - Porto Alegre, PMPA/SPM, 1979.

PRELORAN, J. "Conceptos éticos e estéticos en cine etnográfico", in Rossi. El Cine Documental Etnobiográfico de Jorge Preloran. Buenos Aires, Busqueda, 1987. P73119.

RICOUER, Paul. Tempo e Narrativa. Tomos I, II e III. Campinas, Papirus, 1994.

RICOUER, Paul. Teoria da Interpretação. Lisboa, Edições 70, 1976.

ROCHA, A. L. Carvalho da Le sanctuaire du désordre, ou l'art de savoir-vivre des douces barbares sous les Tristes Tropiques. Tese de doutoramento defendida na Universidade de Paris V, Sorbonne, 1994, sob a direção de Michel Maffesolli.

ROCHA, A. L. Carvalho da As figurações de lendas e mitos históricos na construção da Cidade tropical. Iluminuras: Série do Banco de Imagens e Efeitos Visuais, número 34. Porto Alegre: BIEV, PPGAS/UFRGS, 2000.

ROCHA, A.L.C. "Antropologia das formas sensíveis; entre o visível e o invisível, a floração de símbolos”. In: Horizontes Antropológicos, Antropologia Visual, Ano 1, vol2, 1995.

ROSA, Guimarães. Primeiras estórias. Rio de Janeiro, José Olympio Ed., 1974.

SAHLINS, Marshall. Ilhas de História. Rio de Janeiro, Zahar, 1981.

SECRETARIA MUNICIPAL Da CULTURA. Porto Alegre. Centro de Pesquisa Histórica. Arquipélago: as ilhas de Porto Alegre. GOMES, José Juvenal; MACHADO, Helena Vitória dos Santos e VENTIMIGLIA, Marise Antunes. Porto Alegre: EU, 1995. SIMMEL, G. A filosofia da paisagem. REVISTA POLÍTICA \& TRABALHO, setembro de 1996. PPGS/UFPB, 12....

THIOLLENT, M. Critica metodológica, investigação social e enquete operária. São Paulo, Polis, 1981.

VELHO, Gilberto. Individualismo e Cultura: notas para uma Antropologia da Sociedade Contemporânea. Rio de Janeiro, Zahar, 1981.

VILLAIN, D. Le cadrage au cinéma, l'oeil à la caméra. Paris, Cahiers du Cinéma, s. d. 